Postremediation Dose Assessment for the Former Alba Craft Laboratory Site, Oxford, Ohio

Environmental Assessment Division Argonne National Laboratory

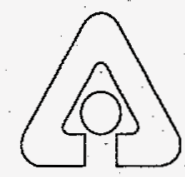

Operated by The University of Chicago, under Contract W-31-109-Eng-38, for the

United States Department of Energy 


\section{Argonne National Laboratory}

Argonne National Laboratory, with facilities in the states of Illinois and Idaho, is owned by the United States Government, and operated by the University of Chicago under the provisions of a contract with the Department of Energy.

This technical memo is a product of Argonne's Environmental Assessment Division (EAD). For information on the division's scientific and engineering activities, contact:

Director, Environmental Assessment Division

Argonne National Laboratory

Argonne, Illinois 60439-4815

Telephone (708) 252-31.07

Presented in this technical memo are preliminary results of ongoing work or work that is more limited in scope and depth than that described in formal reports issued by the EAD.

Publishing support services were provided by Argonne's Information and Publishing Division (for more information, see IPD's home page: http://www.ipd.anl.gov/)

\section{Disclaimer}

This report was prepared as an account of work sponsored by an agency of the United States Government. Neither the United States Government nor any agency thereof, nor any of their employees, makes any warranty, express or implied, or assumes any legal liability or responsibility for the accuracy, completeness, or usefulness of any information, apparatus, product, or process disclosed, or represents that its use would not infringe privately owned rights. Reference herein to any specific commercial product, process, or service by trade name, trademark, manufacturer, or otherwise, does not necessarily constitute or imply its endorsement, recommendation, or favoring by the United States Government or any agency thereof. The views and opinions of authors expressed herein do not necessarily state or reflect those of the United States Government or any agency thereof. 


\section{DISCLAIMER}

Portions of this document may be illegible in electronic image products. Images are produced from the best available original document. 


\section{Postremediation Dose Assessment for the Former Alba Craft Laboratory Site, Oxford, Ohio}

by S. Kamboj, M. Nimmagadda, and C. Yu

Environmental Assessment Division,

Argonne National Laboratory, 9700 South Cass Avenue, Argonne, Illinois 60439

April 1996

Work sponsored by U.S. Department of Energy, Office of Environmental Restoration, Washington, D.C.

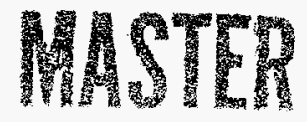

DISTRBUTION OF THS DOCUMENT IS UNLMTTEO BS 


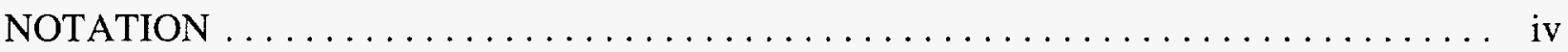

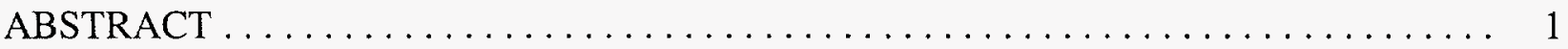

1 INTRODUCTION AND BRIEF HISTORY $\ldots \ldots \ldots \ldots \ldots \ldots \ldots \ldots \ldots \ldots \ldots \ldots$

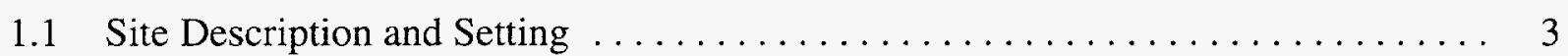

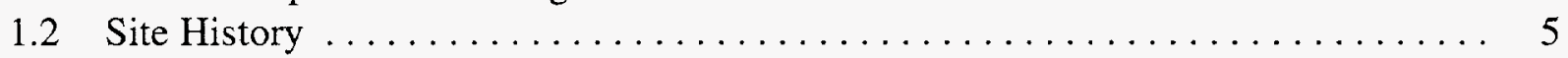

1.3 Summary of Remedial Action Activities $\ldots \ldots \ldots \ldots \ldots \ldots \ldots \ldots$

2 SCENARIO DEFINITIONS $\ldots \ldots \ldots \ldots \ldots \ldots \ldots \ldots \ldots \ldots \ldots \ldots \ldots$

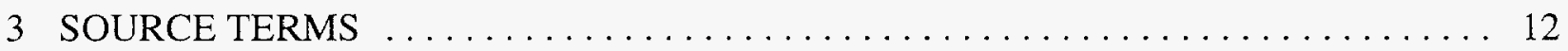

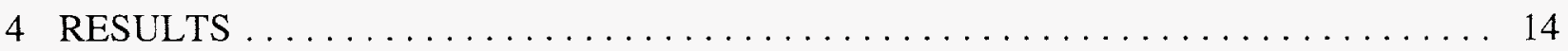

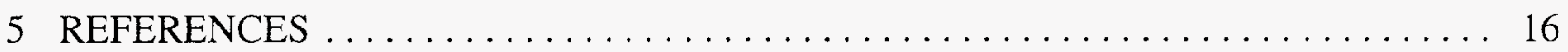

APPENDIX: Scenarios and Parameters Used for the Analysis

of the Former Alba Craft Laboratory Site . . . . . . . . . . . . . 17

\section{FIGURES}

1 Location of the Former Alba Craft Laboratory Site, Oxford, Ohio $\ldots \ldots \ldots \ldots$

2 Map of the Former Alba Craft Laboratory Site and Vicinity Properties

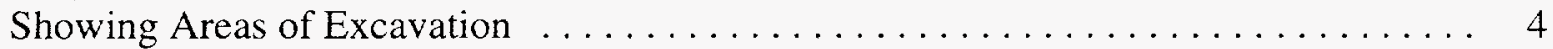

\section{TABLES}

1 Summary of Exposure Pathways for Scenarios A, B, and C at the Former Alba Craft Laboratory Site

2 Radionuclide Concentrations Used in the RESRAD Code for Analysis of the Former Alba Craft Laboratory Site $\ldots \ldots \ldots \ldots \ldots \ldots \ldots \ldots \ldots \ldots$

3 Summary of the Potential Maximum Dose Rates for Scenarios A, B, and C at the Former Alba Craft Laboratory Site

A.1 Parameters Used in the RESRAD Computer Code for Analysis of the Former Alba Craft Laboratory Site 
The following is a list of the acronyms, initialisms, and abbreviations (including units of measure) used in this document. Some acronyms used only in tables or equations are defined in the respective tables or equations.

\section{ACRONYMS, INITIALISMS, AND ABBREVIATIONS}

$\begin{array}{ll}\text { AEC } & \text { U.S. Atomic Energy Commission } \\ \text { ALARA } & \begin{array}{l}\text { as low as reasonably achievable } \\ \text { BNI }\end{array} \\ \text { Bechtel National Incorporated } \\ \text { DOE } & \text { U.S. Department of Energy } \\ \text { FUSRAP } & \text { Formerly Utilized Sites Remedial Action Program } \\ \text { NLO } & \text { National Lead of Ohio } \\ \text { ORNL } & \text { Oak Ridge National Laboratory } \\ \text { RESRAD } & \text { residual radioactive material guideline computer code }\end{array}$

\section{UNITS OF MEASURE}

$\begin{array}{ll}\mathrm{cm} & \text { centimeter(s) } \\ \mathrm{cm}^{2} & \text { square centimeter(s) } \\ \mathrm{cm}^{3} & \text { cubic centimeter(s) } \\ \mathrm{d} & \text { day(s) } \\ \mathrm{dpm} & \text { disintegration(s) per minute } \\ \mathrm{ft} & \text { foot (feet) } \\ \mathrm{ft}^{2} & \text { square foot (feet) } \\ \mathrm{g} & \text { gram(s) } \\ \mathrm{h} & \text { hour(s) } \\ \mathrm{in.} & \text { inch(es) } \\ \mathrm{kg} & \text { kilogram(s) } \\ \mathrm{km} & \text { kilometer(s) }\end{array}$

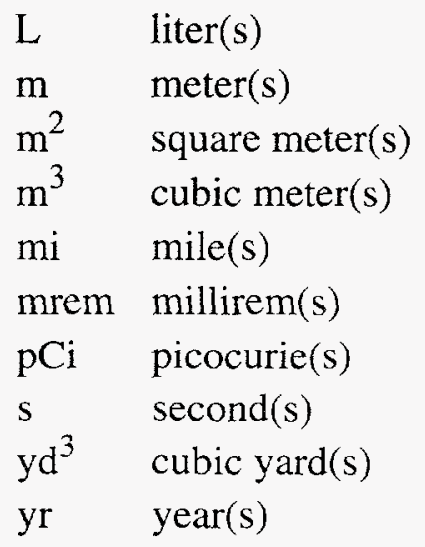




\title{
POSTREMEDIATION DOSE ASSESSMENT FOR THE FORMER ALBA CRAFT LABORATORY SITE, OXFORD, OHIO
}

\author{
by
}

\author{
S. Kamboj, M. Nimmagadda, and C. Yu
}

\begin{abstract}
Potential maximum radiation dose rates were calculated for the former Alba Craft Laboratory site in Oxford, Ohio, which was involved in machining of uranium metal in the 1950s. The site is not currently being used. The residual radioactive material guideline (RESRAD) computer code, which implements the methodology described in the U.S. Department of Energy's (DOE's) manual for establishing residual radioactive material guidelines, was used in this evaluation. Three potential land use scenarios were considered for the former Alba Craft site; the scenarios vary with regard to the type of site use, time spent at the site by the exposed individual, and sources of food consumed. Scenario A (a possible land use scenario) assumed industrial use of the site; Scenario B (a likely future land use scenario) assumed residential use of the site; and Scenario $\mathrm{C}$ (a possible but unlikely land use scenario) assumed the presence of a resident farmer. For Scenario A, it was assumed that any water used for domestic or industrial activities would be from uncontaminated off-site municipal sources. The water used for drinking, household purposes, and irrigation was assumed to be from uncontaminated municipal sources in Scenario B; groundwater drawn from a well located at the downgradient edge of the contaminated zone would be the only source of water for drinking, irrigation, and raising livestock in Scenario $\mathrm{C}$. The results of the evaluation indicated that the DOE dose limit of $100 \mathrm{mrem} / \mathrm{yr}$ would not be exceeded for any of the scenarios analyzed. The potential maximum dose rates for Scenarios A, B, and C are $0.64,2.0$, and $11 \mathrm{mrem} / \mathrm{yr}$, respectively.
\end{abstract}

\section{INTRODUCTION AND BRIEF HISTORY}

The former Alba Craft Laboratory site in Oxford, Ohio (Figure 1), is part of the Formerly Utilized Sites Remedial Action Program (FUSRAP), a U.S. Department of Energy (DOE) program for decontaminating or otherwise controlling sites where residual radioactive materials remain from the early years of the U.S. atomic energy program or from commercial operations causing 


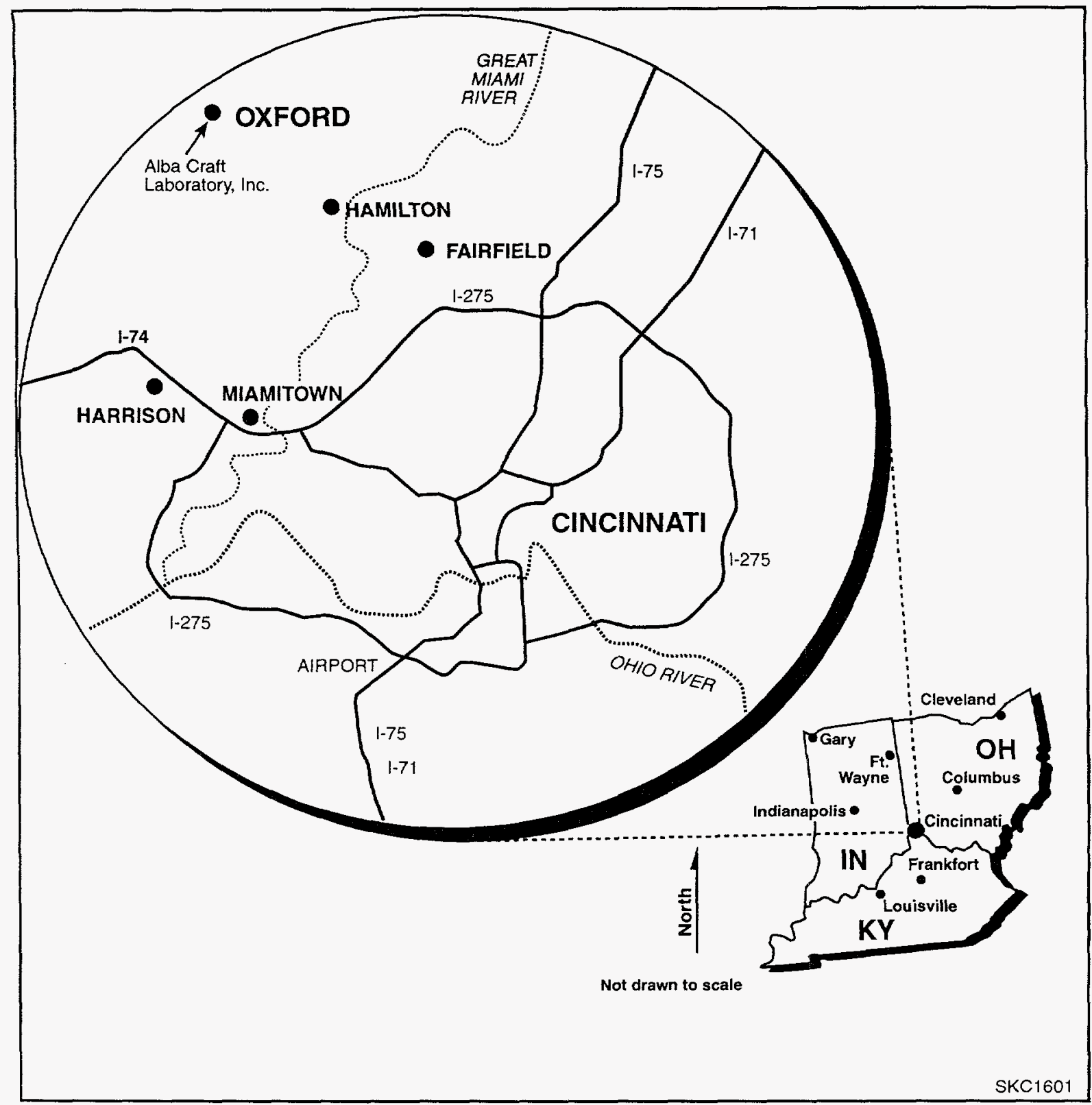

FIGURE 1 Location of the Former Alba Craft Laboratory Site, Oxford, Ohio (Source: Adapted from Murray et al. 1993) 
conditions that Congress has authorized the DOE to remedy. The former Alba Craft Laboratory is a FUSRAP site not owned by the DOE.

Remedial action was conducted at the site in 1995. Postremedial action surveys and soil sample analyses confirm that the remediated areas contain no radioactivity exceeding DOE guidelines (Bechtel National Incorporated [BNI] 1995). In addition, an independent verification survey confirmed that the site was adequately characterized to identify the types and areal extent of contaminants and that remedial actions had been effective in reducing contamination to levels below the DOE guidelines and authorized limits. The purpose of this report is to calculate potential maximum radiation dose rates for possible future land use conditions on the basis of postremediation concentrations of radioactive material in soil. The residual radioactive material guideline (RESRAD) computer code (version 5.61), which implements the methodology described in DOE's manual for establishing residual radioactive material guidelines (Yu et al. 1993a), was used to perform a dose assessment for the former Alba Craft site and its vicinity properties.

\subsection{SITE DESCRIPTION AND SETTING}

Before remediation, the Alba Craft Laboratory site was occupied by three structures that had been joined to appear as one building. At the time of a radiological survey performed by Oak Ridge National Laboratory (ORNL), the building complex was being used to support three independent businesses. The east wing contained a chemistry laboratory and supporting offices, the west wing was used to produce custom embroidered products such as shirts and caps, and the north wing was leased to a contractor to store packaged foods (Murray et al. 1993). The building complex was surrounded on the east, north, and south sides by residential homes and apartments (Figure 2).

The town of Oxford is located in Butler County, Ohio. Hydrogeologic information from a study of groundwater conditions in the Oxford area (Smith 1982) was used to characterize the contaminated zone, unsaturated zone, and saturated zone. This information was used to model contaminant transport in groundwater beneath the former Alba Craft Laboratory site because no boreholes have been drilled to obtain site-specific data. The topsoil and subsoils in the area typically extend to a depth of $2.4 \mathrm{~m}$ and are followed by layers of clay, sandy soil, sand gravel, and blue clay. Interbedded limestones and shales of the Cincinnatian Series are present below a depth of $10 \mathrm{~m}$ and can extend to depths greater than $400 \mathrm{~m}$. These limestones and shales form an effective aquitard, and wells in the area tap the groundwater in the sand and gravel layers located approximately 6 to $8 \mathrm{~m}$ below the surface (Smith 1982). The mean annual precipitation in the area is about $103 \mathrm{~cm}$. The average annual runoff is about $21 \%$ of the average precipitation, and evapotranspiration is approximately $57 \%$ of the average precipitation (Smith 1982). 


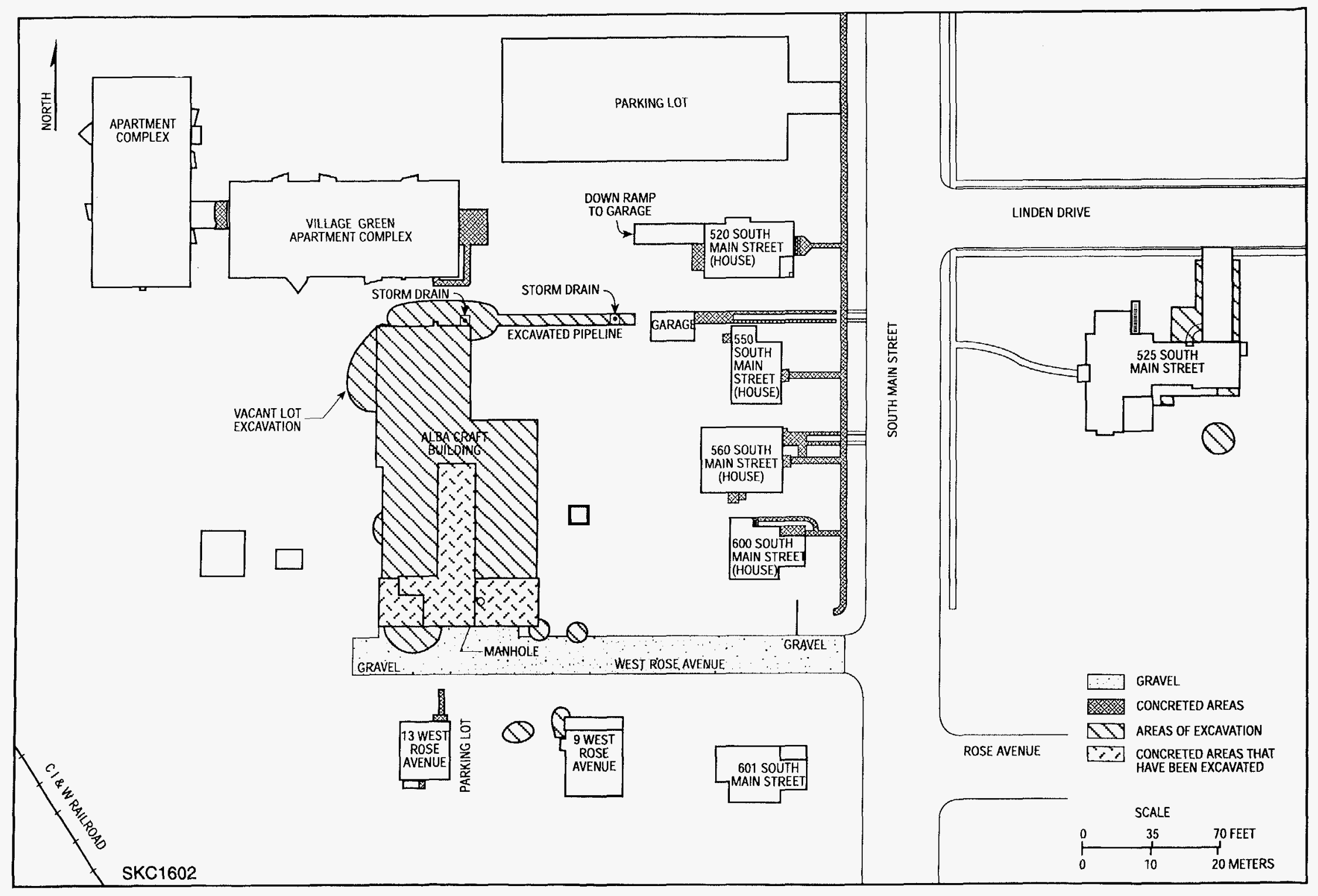

FIGURE 2 Map of the Former Alba Craft Laboratory Site and Vicinity Properties Showing Areas of Excavation (Source: Adapted from Murray et al. 1993) 


\subsection{SITE HISTORY}

Alba Craft Laboratory, Incorporated, was a subcontractor to National Lead of Ohio (NLO) from approximately October 1952 to February 1957. Alba Craft performed a variety of machine shop operations on natural uranium metal for NLO, a primary contractor for the U.S. Atomic Energy Commission (AEC). Early work included general machining and developmental machining of threaded uranium slugs for the Savannah River Site in Aiken, South Carolina. Final operations were on a large production scale and consisted of hollow drilling and turning uranium slugs for reactors at the Savannah River Site and the Hanford Site in Richland, Washington. In 1954, the Alba Craft facilities were also used directly by NLO, which supplied its own operators and materials for machining. The total quantity of uranium machined by Alba Craft is estimated at several hundred tons; the quantity machined by NLO during 1954 is unknown.

As a result of the industrial activities performed at the site, equipment, buildings, and land at some of the adjacent vicinity properties became contaminated with low levels of radioactive material. In January 1957, at contract termination, Alba Craft personnel decontaminated sites used by contractors to the specifications outlined by the NLO Industrial Hygiene Department. Since the time of the original assessment, more stringent radiological criteria and guidelines have been implemented for the release of such sites for unrestricted use.

In May 1988, the building complex was bought and renovated. The new owner then began using it for various business enterprises. The renovations included remodeling the east wing with stud walls, a drop ceiling, and carpet. Little remodeling was performed on the west and north wings. In addition, the outside area between the east and west wings was covered with concrete and was used to provide access for delivery vehicles.

As a follow-up to previous investigations and as a precaution to ensure that residual radioactive material exceeding current DOE guidelines did not migrate off-site, DOE requested a radiological survey of the former laboratory and vicinity properties. A preliminary inspection in June 1992 indicated the presence of uranium contamination both inside and outside the former Alba Craft building complex.

In July and September 1992, a radiological survey was conducted at the former Alba Craft Laboratory site and vicinity properties. The results indicated that uranium contamination from former AEC-related activities still existed in and around the building complex in quantities exceeding current DOE guidelines (Murray et al. 1993). Exterior areas with radioactive material above DOE site-specific health-based guidelines included the Alba Craft property, an adjacent lot to the west, vicinity properties at 525 South Main Street, portions of the sewer drain at 550 South Main Street, and portions of West Rose Avenue in the immediate vicinity of the Alba Craft site. The property at 525 South Main Street (shown in Figure 2) was also found to have interior radioactive 
contamination. Remedial action was conducted at the site and vicinity properties on the basis of these survey findings.

\subsection{SUMMARY OF REMEDIAL ACTION ACTIVITIES}

The DOE remedial action guidelines for alpha activity on concrete surfaces are $5,000 \mathrm{dpm} / 100 \mathrm{~cm}^{2}$ average, $15,000 \mathrm{dpm} / 100 \mathrm{~cm}^{2}$ maximum, and $1,000 \mathrm{dpm} / 100 \mathrm{~cm}^{2}$ removable (DOE 1990). The DOE guidelines for radium-226, thorium-232, and thorium-230 concentrations in soil are $5 \mathrm{pCi} / \mathrm{g}$ when averaged over the first $15 \mathrm{~cm}$ ( $6 \mathrm{in}$.) of soil below the surface and $15 \mathrm{pCi} / \mathrm{g}$ when averaged over any soil layer $15 \mathrm{~cm}$ ( 6 in.) thick below the surface laver, excluding background concentrations (DOE 1990, 1992). For uranium, a site-specific guideline of $35 \mathrm{pCi} / \mathrm{g}$ was derived (Wagoner 1994). Where contamination exceeded applicable guidelines at the former Alba Craft site, remedial action was conducted until measurements indicated that DOE guideline limits had been met.

Remedial action was conducted at the site from August 1994 through January 1995. The areas that were excavated during remedial action are shown in Figure 2. The on-site buildings were demolished because of their poor condition and the presence of radioactive materials (BNI 1995). All building debris and radioactively contaminated soil were removed and disposed of as low-level radioactive waste. First, the interior of the building complex was surveyed, and the hot spots were remediated to minimize off-site releases and overall exposure during demolition. The underlying and surrounding soil was excavated as necessary to remove any radioactive material found beneath or around the building foundation. A contaminated sewer drain in the northeast corner of the building, which extended onto the adjacent property at 550 South Main Street, was also excavated, along with the contaminated soil surrounding the drainpipe. After remediation, the interior areas of the property at 525 South Main Street were decontaminated and restored to their original condition. The exterior areas that were excavated included flower beds in the front and rear of the house and along both sides of the driveway, and a small area in the backyard. All excavated areas were recontoured and reseeded after postremediation action surveys had been completed (BNI 1995). Radioactively contaminated soil was also excavated from a small area (covering about $37 \mathrm{~m}^{2}$ ) of West Rose Avenue in front of the Alba Craft building and a small section (covering about $4.7 \mathrm{~m}^{2}$ ) at 9 West Rose Avenue (Figure 2).

Approximately $2,100 \mathrm{~m}^{3}$ of low-level radioactive waste was generated during the demolition and excavation of the former Alba Craft Laboratory and remediation of the vicinity properties. Concrete rubble and cinder blocks from demolition of the Alba Craft building complex were processed into a soil-like consistency to facilitate packaging and disposal. Building debris, processed materials, and excavated soil were packaged and shipped to the Envirocare of Utah disposal facility in Clive, Utah (BNI 1995). No excavated soil or debris was used as backfill material on any property at the Alba Craft site. 
As remedial actions were completed, radiological surveys were conducted to confirm that no radioactivity exceeding DOE guidelines remained in the remediated areas. These surveys included direct surface measurements and analysis of soil samples collected from excavated areas. Survey results indicated that the areas previously identified as exceeding guidelines during characterization activities had been successfully brought into compliance with applicable DOE cleanup guidelines for radioactive contamination (BNI 1995). 


\section{SCENARIO DEFINITIONS}

Although the former Alba Craft site is not currently being used, three potential exposure scenarios were considered for assessing postremediation dose. For these scenarios, it was assumed that at some time within 1,000 years, the site would be released for use without radiological restrictions. Potential radiation doses resulting from nine exposure pathways were considered: (1) direct exposure to external radiation from decontaminated soil material; (2) internal radiation from inhalation of contaminated dust; (3) internal radiation from inhalation of emanating radon-222; (4) internal radiation from ingestion of plant foods grown in the decontaminated area and irrigated with water drawn from a well located at the downgradient edge of the decontaminated area; (5) internal radiation from ingestion of meat from livestock fed with fodder grown in the decontaminated area and irrigated with water drawn from an on-site well; (6) internal radiation from ingestion of milk obtained from livestock fed with fodder grown in the decontaminated area and irrigated with water drawn from an on-site well; (7) internal radiation from ingestion of fish from a pond downgradient from the decontaminated area; (8) internal radiation from incidental ingestion of on-site soil; and (9) internal radiation from drinking water drawn from an on-site well. All exposure pathways considered for the three scenarios (Scenarios A, B, and C) are summarized in Table 1.

Scenario A (a possible land use scenario) assumed industrial use of the site. Under this scenario, a hypothetical individual was assumed to work 8 hours per day at the site (6 hours working outdoors and 2 hours indoors), 5 days per week, 50 weeks per year. It was also assumed that the worker would not ingest water, plant foods, or fish obtained from the remediated area or meat or milk from livestock raised in the remediated area. For this scenario, it was assumed that any water used for domestic or industrial activities would be from uncontaminated off-site municipal sources. The dose to the worker was assumed to be only from the remediated soil.

Scenario B (a likely future land use scenario) assumed residential use of the site. It was assumed that at some time in the future, the whole site would be transformed into a residential area. Under this scenario, during one year, a hypothetical resident was assumed to spend $50 \%$ of the time indoors in the remediated area; $25 \%$ of the time outdoors in the remediated area; and $25 \%$ of the time away from the site. The resident was assumed to ingest plant foods grown in a garden on the site. All water used by the resident for drinking, household purposes, and irrigation would be from municipal sources that were not radioactively contaminated. For this scenario, it was assumed that no livestock would be raised on the site for the production of meat and milk and that no pond would be present to provide fish or other aquatic food. 
TABLE 1 Summary of Exposure Pathways for Scenarios A, $\mathrm{B}$, and $\mathrm{C}$ at the Former Alba Craft Laboratory Site

\begin{tabular}{lccc}
\hline \multicolumn{1}{c}{ Pathway } & Scenario $\mathrm{A}^{\mathrm{a}}$ & Scenario B $^{\mathrm{b}}$ & Scenario $^{\mathrm{c}}$ \\
\hline External gamma exposure & Yes & Yes & Yes \\
Inhalation of dust & Yes & Yes & Yes \\
Inhalation of radon & Yes & Yes & Yes \\
Ingestion of plant foods & No & Yes & Yes \\
Ingestion of meat & No & No & Yes \\
Ingestion of milk & No & No & Yes \\
Ingestion of fish & No & No & Yes \\
Ingestion of soil & Yes & Yes & Yes \\
Ingestion of water & No & No & Yes \\
\hline
\end{tabular}

a Industrial worker: no consumption of water or food obtained on the site.

b Resident: water used for drinking and household purposes, and for irrigation assumed to be from uncontaminated municipal sources.

c Subsistence farmer: water used for drinking, household purposes, and livestock watering, and irrigation assumed to be from an on-site well.

Scenario C (a plausible but unlikely future land use scenario) was similar to Scenario B, in that a resident was assumed to ingest plant foods grown in the garden. However, under Scenario $\mathrm{C}$, the resident would be a subsistence farmer who would also ingest meat and milk from livestock fed with forage grown on-site and catch and consume fish and other aquatic organisms from an on-site pond. For this scenario, the groundwater drawn from a well located on-site would be the only water source for drinking, household use, livestock watering, and irrigation. No agricultural activity currently occurs at the site, and production of livestock or construction of a fishing pond in the decontaminated area is considered extremely unlikely.

The RESRAD computer code (version 5.61) (Yu et al. 1993a) was used to calculate the potential radiation doses for the hypothetical future industrial worker (Scenario A), resident (Scenario B), and subsistence farmer (Scenario C) on the basis of the following assumptions:

- During one year, the industrial worker would spend 1,500 hours (17\% of his or her time) outdoors at the decontaminated site, 500 hours $(6 \%)$ indoors at the site, and 6,760 hours (77\%) away from the site. (This assumption is more conservative than a typical site-specific guideline scenario where the industrial worker is assumed to spend 500 hours [6\%] outdoors at the decontaminated 
site and 1,500 hours [17\%] indoors at the site.) During one year, the resident and the subsistence farmer (Scenarios B and C) would each spend 4,380 hours (50\% of their time) indoors at the decontaminated site, 2,190 hours (25\%) outdoors at the site, and 2,190 hours (25\%) away from the site (Yu et al. 1993a).

- The total remediated area of $1,350 \mathrm{~m}^{2}$ consists of one large area $\left(1,240 \mathrm{~m}^{2}\right)$ and nine smaller noncontiguous areas $\left(110 \mathrm{~m}^{2}\right)$. For conservatism and consistency with the guideline report (Nimmagadda et al. 1994), the entire area of the site $\left(3,000 \mathrm{~m}^{2}\right)$ and an average depth of $0.5 \mathrm{~m}$ was used in this analysis.

- The walls, floor, and foundation of the house (Scenarios B and C) or commercial building (Scenario A) would reduce external exposure by $30 \%$. The indoor dust level would be $40 \%$ of the outdoor dust level (Yu et al. 1993a).

- The depth of the house or building foundation was set to maximize the radon inhalation dose but not to exceed $1 \mathrm{~m}$ below ground surface (RESRAD default -1), with an effective radon diffusion coefficient of $3 \times 10^{-7} \mathrm{~m}^{2} / \mathrm{s}$ (Yu et al. 1993a).

- The size of the remediated area is sufficiently large $\left(3,000 \mathrm{~m}^{2}\right)$ to provide $10 \%$ of the plant food diet consumed by the resident (Scenario B) and $50 \%$ of that consumed by the subsistence farmer (Scenario C) from a garden in the decontaminated area ( $\mathrm{Yu}$ et al. 1993a). The industrial worker would not consume these plant foods.

- The size of the remediated area is sufficiently large to produce $15 \%$ of the forage used to feed livestock for meat and milk consumed by the subsistence farmer in Scenario C (Yu et al. 1993a). The animal products consumed by the industrial worker in Scenario A and the resident in Scenario B would not be from livestock raised on the site.

- For Scenario C, 50\% of the fish and other aquatic food consumed by the subsistence farmer would be obtained from an on-site pond (Yu et al. 1993a).

- After remedial action, about $2,100 \mathrm{~m}^{3}$ of clean fill was placed over the site, which provided $0.7 \mathrm{~m}$ of clean cover over the site. However, to be more conservative, cover thickness was assumed to be zero in the RESRAD calculations. 
- No soil erosion occurs.

- The current water supply for the site is from municipal sources. However, for the plausible but unlikely land use scenario (Scenario C), the source of water for drinking, household uses, livestock watering, and irrigation was assumed to be an on-site well. 


\section{SOURCE TERMS}

The source term concentrations used in the RESRAD computer code analysis of the site were calculated with data collected from a postremedial soil survey around the former Alba Craft facility (BNI 1995). Thirty-two soil samples were collected from areas excavated during the remedial action -25 from the Alba Craft building complex area and 7 from 525 South Main Street (BNI 1995). The survey measured residual concentrations of uranium-238 and total uranium. The results of the soil sample analyses indicate that radionuclide concentrations do not exceed the DOE remedial action guidelines (Wagoner 1994). Average background concentrations were also reported in the postremedial soil survey report (BNI 1995). The average background concentrations were based on analysis of soil samples taken from three locations within an $8-\mathrm{km}$ radius of the site.

All exposure scenarios analyzed assumed that the construction of a house or industrial building would result in excavation and mixing of on-site soil. Because of this excavation and mixing, the estimates of radionuclide concentrations for the entire site were based on the arithmetic average of soil data given in the postremedial survey report (Tables 4-3 and 4-7 in BNI 1995). The average radionuclide concentrations for uranium-238 for the entire site were used in this assessment (background concentrations were subtracted). Concentrations of uranium-234 and uranium-235 were inferred on the basis of the assumption that uranium-238, uranium-234, and uranium-235 are present in their natural activity concentration ratio of 1:1:0.046. Furthermore, the concentrations of actinium-227 and protactinium-231 were assumed to be in secular equilibrium with uranium-235. Radium-226 and thorium-230 concentrations in the characterization samples were extremely low (BNI 1995). The radionuclide concentrations used in the RESRAD computer code are presented in Table 2, and the various parameters used in the code are listed in the Appendix. Except for the radionuclide concentrations, all values used in the RESRAD computer code were those previously used to derive the uranium guidelines for the site (Nimmagadda et al. 1994). 
TABLE 2 Radionuclide Concentrations (pCi/g) Used in the RESRAD Code for Analysis of the Former Alba Craft Laboratory Site

\begin{tabular}{lccc}
\hline Radionuclide & $\begin{array}{c}\text { Average } \\
\text { Radionuclide } \\
\text { Concentration }^{\mathrm{a}}\end{array}$ & $\begin{array}{c}\text { Average } \\
\text { Background } \\
\text { Radionuclide } \\
\text { Concentration }^{\mathrm{b}}\end{array}$ & $\begin{array}{c}\text { Radionuclide } \\
\text { Concentration } \\
\text { Used in } \\
\text { RESRAD }^{\mathrm{c}}\end{array}$ \\
\hline Uranium-238 & 4.79 & 0.86 & 3.93 \\
Uranium-234 & $-{ }^{\mathrm{d}}$ & - & $3.93^{\mathrm{e}}$ \\
Uranium-235 & - & - & $0.18^{\mathrm{e}}$ \\
Actinium-227 & - & - & $0.18^{\mathrm{f}}$ \\
Protactinium-231 & - & - & $0.18^{\mathrm{f}}$ \\
Radium-226 & Trace $^{\mathrm{g}}$ & 1.0 & 0 \\
Thorium-230 & Trace $^{\mathrm{g}}$ & 0.96 & 0 \\
\hline
\end{tabular}

a Average radionuclide concentrations were calculated on the basis of soil data given in Tables 4-3 and 4-7 of BNI (1995).

b Source: Table 2 of Murray et al. (1993).

c The background radionuclide concentration is subtracted from the average radionuclide concentration.

d "." indicates that the concentration of this radionculide was not measured.

e Concentration based on the assumption that uranium-238, uranium-234, and uranium-235 are present in their natural activity concentration ratio of 1:1:0.046.

$f$ Concentration based on the assumption that the radionuclide is in secular equilibrium with uranium-235.

$\mathrm{g}$ Source: BNI (1995). 


\section{RESULTS}

The RESRAD computer code was used to calculate the potential radiation doses for each exposure scenario. The time frame considered in this analysis was 1,000 years from remediation. Radioactive decay and ingrowth were considered in calculating the maximum dose rates. The various parameters used in the RESRAD code for this analysis are listed in the Appendix. The calculated maximum dose rates for Scenarios A, B, and C are presented in Table 3.

For all scenarios, the maximum calculated dose rate does not exceed the DOE annual limit of $100 \mathrm{mrem} / \mathrm{yr}$ (DOE 1990, 1992). For Scenarios A (industrial worker) and B (resident: municipal water supply), the maximum dose would occur at time zero (tne year the postremediation radiological survey was conducted). For Scenario C (resident: on-site well water), the time at which the maximum dose rate would occur is 249 years following the postremediation radiological survey. The maximum dose rates for Scenarios $\mathrm{A}$ and $\mathrm{B}$ are 0.64 and $2 \mathrm{mrem} / \mathrm{yr}$, respectively. For these two scenarios, inhalation of dust and external exposure would be the dominant pathways, contributing approximately $90 \%$ and $70 \%$ of the total annual dose for Scenarios A and B, respectively. For Scenario C, the maximum dose rate is $11 \mathrm{mrem} / \mathrm{yr}$. Ingestion of groundwater accounts for about $90 \%$ of the total annual dose. 
TABLE 3 Summary of the Potential Maximum Dose Rates for Scenarios A, B, and C at the Former Alba Craft Laboratory Site ${ }^{\text {a }}$

Dose Rates (mrem/yr)

\begin{tabular}{lccc}
\multicolumn{1}{c}{ Pathway } & Scenario A & Scenario B & Scenario C \\
\hline External gamma exposure & $2.1 \times 10^{-1}$ & $5.9 \times 10^{-1}$ & $3.0 \times 10^{-2}$ \\
& & & \\
Inhalation & & & \\
$\quad$ Dust & $3.8 \times 10^{-1}$ & $8.8 \times 10^{-1}$ & $4.1 \times 10^{-2}$ \\
Radon & 0 & 0 & $4.8 \times 10^{-3}$ \\
& & & \\
Ingestion & & & \\
Plant foods & $\mathrm{NA}$ & $3.0 \times 10^{-1}$ & $8.2 \times 10^{-1}$ \\
Meat & $\mathrm{NA}$ & $\mathrm{NA}$ & $4.3 \times 10^{-2}$ \\
Milk & $\mathrm{NA}$ & $\mathrm{NA}$ & $1.2 \times 10^{-2}$ \\
Fish & $\mathrm{NA}$ & $\mathrm{NA}$ & $1.4 \times 10^{-1}$ \\
Soil & $5.7 \times 10^{-2}$ & $1.9 \times 10^{-1}$ & $9.0 \times 10^{-3}$ \\
Water & $\mathrm{NA}$ & $\mathrm{NA}$ & 9.6 \\
& & & \\
Total & $6.4 \times 10^{-1}$ & 2.0 & $1.1 \times 10^{1}$ \\
\hline
\end{tabular}

a For Scenarios A and B, the maximum dose would occur at time zero (the year the postremediation radiological survey was conducted). For Scenario C, the maximum dose rate would occur 249 years after the postremediation survey.

b NA = not applicable because it is not a pathway of concern.

c Municipal water is used for drinking in Scenarios A and B, and only water from an on-site well is used for drinking, irrigation, and livestock watering for Scenario $\mathrm{C}$. 


\section{REFERENCES}

Bechtel National Incorporated, 1995, Post-Remedial Action Report for the Alba Craft Site and Vicinity Properties, DOE/OR/21949-387, U.S. Department of Energy, Oak Ridge Operations Office, Oak Ridge, Tenn., Aug.

BNI: See Bechtel National Incorporated.

DOE: See U.S. Department of Energy.

Murray, M.E., et al., 1993, Results of the Radiological Survey at the Former Alba Craft Laboratory Site Properties, Oxford, Ohio (OXOOO1), ORNL/RASA-92/14, Oak Ridge National Laboratory, Health and Safety Research Division, Oak Ridge, Tenn., March.

Nimmagadda, M., et al., 1994, Derivation of Uranium Residual Radioactive Material Guidelines for the Former Alba Craft Laboratory Site, ANL/EAD/TM-9, Argonne National Laboratory, Argonne, Ill., Jan.

Smith, B.S., 1982, Occurrence and Quality of Ground Water in the Oxford - Morning Sun Area, Ohio, Master's Thesis, Miami University, Oxford, Ohio.

U.S. Department of Energy, 1990, "Radiation Protection of the Public and Environment," DOE Order 5400.5, Washington, D.C., Feb. 8.

U.S. Department of Energy, 1992, Radiological Control Manual, Assistant Secretary for Environment, Safety and Health, Washington, D.C., June.

U.S. Department of Energy, 1994, Engineering Evaluation and Cost Analysis for the Alba Craft Site, Oxford, Ohio, Oak Ridge Operations Office, Oak Ridge, Tenn., Aug.

Wagoner, J.W., 1994, "Uranium Guideline for the Alba Craft Site, Oxford," memorandum from Wagoner (U.S. Department of Energy, Washington, D.C.) to L.K. Price (Oak Ridge Field Office, Oak Ridge, Tenn.), BNI CCN 118575, July 15.

Yu, C., et al., 1993a, Manual for Implementing Residual Radioactive Material Guidelines Using RESRAD, Version 5.0, ANL/EAD/LD-2, Argonne National Laboratory, Argonne, Ill., Sept.

Yu, C., et al., 1993b, Data Collection Handbook to Support Modeling the Impacts of Radioactive Material in Soil, ANL/EAIS-8, Argonne National Laboratory, Argonne, Ill., April. 


\section{APPENDIX \\ SCENARIOS AND PARAMETERS USED FOR THE ANALYSIS OF THE FORMER ALBA CRAFT LABORATORY SITE}

The following exposure scenarios were analyzed for the former Alba Craft Laboratory site in Oxford, Ohio:

- Scenario A: Industrial Use of the Site. A hypothetical person is assumed to work in the area of the site.

- Scenario B: Residential Use of the Site - Municipal Water Supply. A hypothetical resident is assumed to live in the remediated area and to use an uncontaminated municipal water supply for drinking, household purposes, and irrigation. The resident is assumed to ingest plant foods grown on-site; however, no livestock are raised on-site for the production of meat and milk, and no pond is present on-site to provide fish and other aquatic food.

- Scenario C: Residential Use of the Site - On-Site Well Water. A hypothetical resident is assumed to live in the remediated area and to use water from an on-site well for drinking, household purposes, livestock watering, and irrigation. The resident is assumed to ingest plant foods grown in an on-site garden and meat and milk from livestock fed with forage grown on-site. The resident is assumed to catch and consume fish and other aquatic organisms from an on-site pond.

The parametric values used in the RESRAD code for the analysis of the former Alba Craft Laboratory site are listed in Table A.1. All parametric values are reported at up to three significant figures. Some values are specific to the former Alba Craft Laboratory site; others are generic. 
TABLE A.1 Parameters Used in the RESRAD Computer Code for Analysis of the Former Alba Craft Laboratory Site

\begin{tabular}{|c|c|c|c|c|}
\hline \multirow[b]{2}{*}{ Parameter } & \multirow[b]{2}{*}{ Unit } & \multicolumn{3}{|c|}{ Value } \\
\hline & & Scenario A & Scenario B & Scenario C \\
\hline Area of contaminated zone $\mathrm{a}^{\mathrm{a}}$ & $m^{2}$ & 3,000 & 3,000 & 3,000 \\
\hline Thickness of contaminated zone ${ }^{a}$ & $\mathrm{~m}$ & 0.5 & 0.5 & 0.5 \\
\hline Length parallel to aquifer flow ${ }^{a}$ & $\mathrm{~m}$ & 55 & 55 & 55 \\
\hline Initial principal radionuclide concentration ${ }^{a}$ & $\mathrm{pCi} / \mathrm{g}$ & & & \\
\hline Actinium-227 & & 0.18 & 0.18 & 0.18 \\
\hline Protactinium-231 & & 0.18 & 0.18 & 0.18 \\
\hline Uranium-234 & & 3.93 & 3.93 & 3.93 \\
\hline Uranium-235 & & 0.18 & 0.18 & 0.18 \\
\hline Uranium-238 & & 3.93 & 3.93 & 3.93 \\
\hline Cover depth ${ }^{\mathrm{a}}$ & $\mathrm{m}$ & 0 & 0 & 0 \\
\hline \multicolumn{5}{|l|}{ Contaminated zone } \\
\hline Density ${ }^{b}$ & $\mathrm{~g} / \mathrm{cm}^{3}$ & 1.5 & 1.5 & 1.5 \\
\hline Erosion rate $^{\mathrm{a}}$ & $\mathrm{m} / \mathrm{yr}$ & 0 & 0 & 0 \\
\hline Total porosity ${ }^{a}$ & $-^{c}$ & 0.4 & 0.4 & 0.4 \\
\hline Effective porosity ${ }^{a}$ & $-^{c}$ & 0.2 & 0.2 & 0.2 \\
\hline Hydraulic conductivity & $\mathrm{m} / \mathrm{yr}$ & 10 & 10 & 10 \\
\hline Soil-specific $b$ parameter ${ }^{a}$ & $-c$ & 5.3 & 5.3 & 5.3 \\
\hline Evapotranspiration coefficient ${ }^{a}$ & $-^{c}$ & 0.57 & 0.57 & 0.57 \\
\hline Precipitation $^{\mathrm{a}}$ & $\mathrm{m} / \mathrm{yr}$ & 1.03 & 1.03 & 1.03 \\
\hline Irrigation $^{b}$ & $\mathrm{~m} / \mathrm{yr}$ & 0.2 & 0.2 & 0.2 \\
\hline Irrigation mode ${ }^{b}$ & $-^{c}$ & Overhead & Overhead & Overhead \\
\hline Runoff coefficient $^{\mathrm{a}}$ & $-^{c}$ & 0.21 & 0.21 & 0.21 \\
\hline Watershed area for nearby pond ${ }^{\mathrm{b}}$ & $\mathrm{m}^{2}$ & Not used & Not used & $1,000,000$ \\
\hline Accuracy for water/soil computation ${ }^{b}$ & $-^{c}$ & Not used & Not used & 0.001 \\
\hline \multicolumn{5}{|l|}{ Saturated zone } \\
\hline Density $^{\mathrm{a}}$ & $\mathrm{g} / \mathrm{cm}^{3}$ & Not used & Not used & 1.5 \\
\hline Total porosity ${ }^{\mathrm{a}}$ & $-^{c}$ & Not used & Not used & 0.34 \\
\hline Effective porosity ${ }^{\mathrm{a}}$ & $-^{c}$ & Not used & Not used & 0.28 \\
\hline Hydraulic conductivity ${ }^{a}$ & $\mathrm{~m} / \mathrm{yr}$ & Not used & Not used & 5,000 \\
\hline Hydraulic gradient ${ }^{a, b}$ & $-^{c}$ & Not used & Not used & 0.02 \\
\hline Soil-specific b parameter ${ }^{a}$ & $-^{c}$ & Not used & Not used & 5.3 \\
\hline Water table drop rate $e^{a, b}$ & $\mathrm{~m} / \mathrm{yr}$ & Not used & Not used & 0 \\
\hline Well pump intake depth (below water table) (a, $^{\text {a }}$ & $\mathrm{m}$ & Not used & Not used & 2.1 \\
\hline $\begin{array}{l}\text { Model: nondispersion }(\mathrm{ND}) \text { or mass } \\
\text { balance }(\mathrm{MB})^{\mathrm{b}}\end{array}$ & $-^{c}$ & Not used & Not used & ND \\
\hline Well pumping rate ${ }^{a, b}$ & $\mathrm{~m}^{3} / \mathrm{yr}$ & Not used & Not used & 250 \\
\hline
\end{tabular}


TABLE A.1 (Cont.)

\begin{tabular}{|c|c|c|c|c|}
\hline \multirow[b]{2}{*}{ Parameter } & \multirow[b]{2}{*}{ Unit } & \multicolumn{3}{|c|}{ Value } \\
\hline & & Scenario A & Scenario B & Scenario $\mathrm{C}$ \\
\hline Number of unsaturated zone strata ${ }^{a}$ & $-^{\mathrm{c}}$ & Not used & Not used & 2 \\
\hline \multicolumn{5}{|l|}{ Unsaturated zone 1} \\
\hline Thickness ${ }^{\mathrm{a}}$ & $\mathrm{m}$ & Not used & Not used & 1.7 \\
\hline Soil density ${ }^{a}$ & $\mathrm{~g} / \mathrm{cm}^{3}$ & Not used & Not used & 1.5 \\
\hline Total porosity ${ }^{\mathrm{a}}$ & $-^{c}$ & Not used & Not used & 0.4 \\
\hline Effective porosity ${ }^{\mathrm{a}}$ & $-^{c}$ & Not used & Not used & 0.2 \\
\hline Soil-specific b parameter ${ }^{\mathrm{a}}$ & $-^{c}$ & Not used & Not used & 5.3 \\
\hline Hydraulic conductivity ${ }^{\mathrm{a}}$ & $\mathrm{m} / \mathrm{yr}$ & Not used & Not used & 10 \\
\hline \multicolumn{5}{|l|}{ Unsaturated zone 2} \\
\hline Thickness $^{\mathbf{a}}$ & $\mathrm{m}$ & Not used & Not used & 4 \\
\hline Soil density ${ }^{\mathrm{a}}$ & $\mathrm{g} / \mathrm{cm}^{3}$ & Not used & Not used & 1.5 \\
\hline Total porosity ${ }^{\mathrm{a}}$ & $-^{c}$ & Not used & Not used & 0.42 \\
\hline Effective porosity ${ }^{a}$ & $-^{c}$ & Not used & Not used & 0.06 \\
\hline Soil-specific $b$ parameter $^{a}$ & $-^{c}$ & Not used & Not used & 11.4 \\
\hline Hydraulic conductivity ${ }^{\mathrm{a}}$ & $\mathrm{m} / \mathrm{yr}$ & Not used & Not used & 40 \\
\hline Distribution coefficient ${ }^{\mathrm{a}, \mathrm{b}}$ & $\mathrm{cm}^{3} / \mathrm{g}$ & & & \\
\hline \multicolumn{5}{|l|}{ Contaminated and unsaturated zone } \\
\hline Uranium-234 & & 50 & 50 & 50 \\
\hline Uranium-235 & & 50 & 50 & 50 \\
\hline Uranium-238 & & 50 & 50 & 50 \\
\hline Actinium-227 & & 20 & 20 & 20 \\
\hline Protactinium-231 & & 50 & 50 & 50 \\
\hline Lead-210 & & 100 & 100 & 100 \\
\hline Radium-226 & & 70 & 70 & 70 \\
\hline Thorium-230 & & 60,000 & 60,000 & 60,000 \\
\hline \multicolumn{5}{|l|}{ Saturated zone } \\
\hline Uranium-234 & & 5 & 5 & 5 \\
\hline Uranium-235 & & 5 & 5 & 5 \\
\hline Uranium-238 & & 5 & 5 & 5 \\
\hline Actinium-227 & & 2 & 2 & 2 \\
\hline Protactinium-231 & & 5 & 5 & 5 \\
\hline Lead-210 & & 10 & 10 & 10 \\
\hline Radium-226 & & 7 & 7 & 7 \\
\hline Thorium-230 & & 6,000 & 6,000 & 6,000 \\
\hline Inhalation rate ${ }^{b}$ & $\mathrm{~m}^{3} / \mathrm{yr}$ & 8,400 & 8,400 & 8,400 \\
\hline Mass loading for inhalation ${ }^{a}$ & $\mathrm{~g} / \mathrm{m}^{3}$ & 0.0001 & 0.0001 & 0.0001 \\
\hline
\end{tabular}


TABLE A.1 (Cont.)

\begin{tabular}{|c|c|c|c|c|}
\hline \multirow[b]{2}{*}{ Parameter } & \multirow[b]{2}{*}{ Unit } & \multicolumn{3}{|c|}{ Value } \\
\hline & & Scenario A & Scenario B & Scenario C \\
\hline Shielding factor, inhalation ${ }^{\mathrm{b}}$ & $-^{c}$ & 0.4 & 0.4 & 0.4 \\
\hline Shielding factor, external gamma ${ }^{b}$ & $-^{\mathrm{c}}$ & 0.7 & 0.7 & 0.7 \\
\hline Fraction of time indoors ${ }^{a, b}$ & $\epsilon^{c}$ & 0.06 & 0.5 & 0.5 \\
\hline Fraction of time outdoors ${ }^{a, b}$ & - $^{c}$ & 0.17 & 0.25 & 0.25 \\
\hline Shape factor, external gamma ${ }^{b}$ & $-c$ & 1 & 1 & 1 \\
\hline Dilution length for airborne dust, inhalation ${ }^{b}$ & $\mathrm{~m}$ & 3 & 3 & 3 \\
\hline \multicolumn{5}{|l|}{ Food consumption } \\
\hline Fruits, vegetables, and grain ${ }^{a, b}$ & $\mathrm{~kg} / \mathrm{yr}$ & Not used & 160 & 160 \\
\hline Leafy vegetables $e^{a, b}$ & $\mathrm{~kg} / \mathrm{yr}$ & Not used & 14 & 14 \\
\hline Milk $^{\mathrm{a}, \mathrm{b}}$ & $\mathrm{L} / \mathrm{yr}$ & Not used & Not used & 92 \\
\hline Meat and poultry ${ }^{\mathrm{a}, \mathrm{b}}$ & $\mathrm{kg} / \mathrm{yr}$ & Not used & Not used & 63 \\
\hline Fish $^{\mathrm{a}, \mathrm{b}}$ & $\mathrm{kg} / \mathrm{yr}$ & Not used & Not used & 5.4 \\
\hline Other aquatic food ${ }^{a, b}$ & $\mathrm{~kg} / \mathrm{yr}$ & Not used & Not used & 0.9 \\
\hline Soil ingestion ${ }^{a, b}$ & $\mathrm{~g} / \mathrm{yr}$ & 36.5 & 36.5 & 36.5 \\
\hline Drinking water intake $\mathrm{e}^{\mathrm{a}, \mathrm{b}}$ & $\mathrm{L} / \mathrm{yr}$ & Not used & Not used & 510 \\
\hline Contaminated fraction of food and water & $-^{c}$ & & & \\
\hline Drinking water ${ }^{\mathrm{a}, \mathrm{b}}$ & & Not used & 0 & 1 \\
\hline Household water ${ }^{\mathrm{a}, \mathrm{b}}$ & & Not used & 0 & 1 \\
\hline Livestock water ${ }^{a, b}$ & & Not used & Not used & 1 \\
\hline Irrigation water ${ }^{a, b}$ & & Not used & 0 & 1 \\
\hline Aquatic food $\mathrm{d}^{\mathrm{a}, \mathrm{b}}$ & & Not used & Not used & 0.5 \\
\hline Plant food $\mathrm{d}^{\mathrm{a}, \mathrm{b}}$ & & Not used & 0.1 & $0.5^{\mathrm{d}}$ \\
\hline Meat ${ }^{a, b}$ & & Not used & Not used & $0.15^{\mathrm{d}}$ \\
\hline Milk $^{\mathrm{a}, \mathrm{b}}$ & & Not used & Not used & $0.15^{\mathrm{d}}$ \\
\hline Livestock fodder intake for meat ${ }^{\mathrm{a}, \mathrm{b}}$ & $\mathrm{kg} / \mathrm{d}$ & Not used & Not used & 68 \\
\hline Livestock fodder intake for milk ${ }^{a, b}$ & $\mathrm{~kg} / \mathrm{d}$ & Not used & Not used & 55 \\
\hline Livestock water intake for meat ${ }^{a, b}$ & $\mathrm{~L} / \mathrm{d}$ & Not used & Not used & 50 \\
\hline Livestock water intake for milk ${ }^{a, b}$ & $\mathrm{~L} / \mathrm{d}$ & Not used & Not used & 160 \\
\hline Livestock soil intake $e^{a, b}$ & $\mathrm{~kg} / \mathrm{d}$ & Not used & Not used & 0.5 \\
\hline Mass loading for foliar deposition ${ }^{a, b}$ & $\mathrm{~g} / \mathrm{m}^{3}$ & Not used & 0.0001 & 0.0001 \\
\hline Depth of soil mixing layer ${ }^{b}$ & $\mathrm{~m}$ & 0.15 & 0.15 & 0.15 \\
\hline Depth of roots ${ }^{a, b}$ & $\mathrm{~m}$ & Not used & 0.9 & 0.9 \\
\hline $\begin{array}{l}\text { Groundwater fractional usage (balance } \\
\text { from surface water) }\end{array}$ & $-^{c}$ & & & \\
\hline Drinking water ${ }^{a, b}$ & & Not used & Not used & 1 \\
\hline Household water ${ }^{a, b}$ & & Not used & Not used & 1 \\
\hline
\end{tabular}


TABLE A.1 (Cont.)

\begin{tabular}{|c|c|c|c|c|}
\hline \multirow[b]{2}{*}{ Parameter } & \multirow[b]{2}{*}{ Unit } & \multicolumn{3}{|c|}{ Value } \\
\hline & & Scenario A & Scenario B & Scenario C \\
\hline Livestock water ${ }^{\mathrm{a}, \mathrm{b}}$ & & Not used & Not used & 1 \\
\hline Irrigation $^{\mathrm{a}, \mathrm{b}}$ & & Not used & Not used & 1 \\
\hline Storage times of contaminated foodstuffs & days & & & \\
\hline Fruits, nonleafy vegetables, and grain ${ }^{\mathrm{a}, \mathrm{b}}$ & & Not used & 14 & 14 \\
\hline Leafy vegetables ${ }^{a, b}$ & & Not used & 1 & 1 \\
\hline Fish $^{\mathrm{a}, \mathrm{b}}$ & & Not used & Not used & 7 \\
\hline Crustacea and mollusks $s^{a, b}$ & & Not used & Not used & 7 \\
\hline Milk $^{\mathrm{a}, \mathrm{b}}$ & & Not used & Not used & 1 \\
\hline Meat and poultry ${ }^{\mathrm{a}, \mathrm{b}}$ & & Not used & Not used & 20 \\
\hline Well water ${ }^{a, b}$ & & Not used & Not used & 1 \\
\hline Livestock fodder ${ }^{a, b}$ & & Not used & Not used & 45 \\
\hline $\begin{array}{l}\text { Total porosity of the house or building } \\
\text { foundation }\end{array}$ & $-^{c}$ & 0.1 & 0.1 & 0.1 \\
\hline Volumetric water content of the foundation ${ }^{b}$ & $-^{c}$ & 0.03 & 0.03 & 0.03 \\
\hline Diffusion coefficient for radon gas & $\mathrm{m}^{2} / \mathrm{s}$ & & & \\
\hline In foundation material ${ }^{b}$ & & $3.0 \times 10^{-7}$ & $3.0 \times 10^{-7}$ & $3.0 \times 10^{-7}$ \\
\hline In contaminated zone soil ${ }^{b}$ & & $2.0 \times 10^{-6}$ & $2.0 \times 10^{-6}$ & $2.0 \times 10^{-6}$ \\
\hline Emanating power of radon- $222^{\mathrm{b}}$ & $-^{\mathrm{c}}$ & 0.25 & 0.25 & 0.25 \\
\hline Radon vertical dimension of mixing ${ }^{b}$ & $\mathrm{~m}$ & 2 & 2 & 2 \\
\hline Average annual wind speed ${ }^{\mathrm{b}}$ & $\mathrm{m} / \mathrm{s}$ & 2 & 2 & 2 \\
\hline Average building air exchange rate ${ }^{b}$ & $1 / \mathrm{h}$ & 0.5 & 0.5 & 0.5 \\
\hline Height of building (room) ${ }^{b}$ & $\mathrm{~m}$ & 2.5 & 2.5 & 2.5 \\
\hline Building indoor area factor ${ }^{b}$ & $-^{c}$ & 0 & 0 & 0 \\
\hline Bulk density of house or building foundation ${ }^{b}$ & $\mathrm{~g} / \mathrm{cm}^{3}$ & 2.4 & 2.4 & 2.4 \\
\hline Thickness of house or building foundation ${ }^{b}$ & $\mathrm{~m}$ & 0.15 & 0.15 & 0.15 \\
\hline Building depth below ground surface ${ }^{b}$ & $\mathrm{~m}$ & -1 & -1 & -1 \\
\hline
\end{tabular}

a Values based on site specifications, scenario assumptions, or Yu et al. (1993a,b).

b RESRAD default values.

c Parameter is dimensionless.

d Calculated with the RESRAD computer code. 


\section{REFERENCES FOR APPENDIX}

Yu, C., et al., 1993a, Manual for Implementing Residual Radioactive Material Guidelines Using RESRAD, Version 5.0, ANL/EAD/LD-2, Argonne National Laboratory, Argonne, Ill., Sept.

Yu, C., et al., 1993b, Data Collection Handbook to Support Modeling the Impacts of Radioactive Material in Soil, ANL/EAIS-8, Argonne National Laboratory, Argonne, Ill., April. 